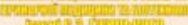

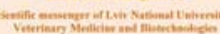

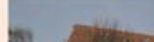

15

10 innm

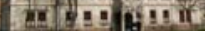

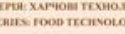
Том 21 Nis 91
Науковий вісник Львівського національного університету ветеринарної медицини та біотехнодогій імені С.3. Гжицького. Серія: Харчові технології

Scientific Messenger of Lviv National University of Veterinary Medicine and Biotechnologies.

Series: Food Technologies

ISSN 2519-268X print

https://nvlvet.com.ua/index.php/food

doi: $10.32718 /$ nvlvet-f9120

UDC 621.9.048.6

\title{
Development and modeling of a device for strengthening the channels of gun barrels by the method of vibration-centrifugal processing
}

\author{
V.I. Topchii, I.S. Aftanasiv, I.G. Svidrak \\ National University “Lviv Polytechnic”, Lviv, Ukraine
}

Article info

Received 04.02.2019

Received in revised form 04.03 .2019

Accepted 05.03.2019

National University "Lviv Polytechnic", S. Bandera Str., 12 Lviv, 790013, Ukraine.

Tel. $+38-066-229-50-87$

E-mail: Vladyslav.I.Topchii@lpnu.ua

svidrak99@gmail.com

Ivan.aftanaziv@gmail.com
Topchii, V.I., Aftanasiv, I.S., \& Svidrak, I.G. (2019). Development and modeling of a device for strengthening the channels of gun barrels by the method of vibration-centrifugal processing. Scientific Messenger of Lviv National University of Veterinary Medicine and Biotechnologies. Series: Food Technologies, 21(91), 118-123. doi: 10.32718/nvlvet-f9120

The paper proposes a fundamentally new method of vibration-centrifugal hardening of internal cylindrical surfaces of long-length steel parts, in particular artillery guns, belonging to a group of methods of surface plastic deformation, and is characterized by providing a significant level of energy for deformation of the material being processed. Artillery cannons, along with a system for targeting shooting guns, are perhaps the most responsible component, which not only provides range and accuracy of the aiming shot, but also regulates the durability of the gun in general. During each of the gun shots, the surface layers of the metal of the channel of its trunk are exposed to the destructive effects of high (up to $10000^{\circ} \mathrm{C}$ ) temperatures, the chemical action of powder gases, excessive pressures and mechanical wear on the movement of the shell. This leads to the destruction of the structure, strength and density of the metal surface layers, its burning and wear, which in the rest, leads to violations of the geometry of the working surface of the trunk channel. Violation of the geometry of the working surface of the channel of the gun barrel negatively affects the range, and most importantly, the precision of gunfire and other precision related tactical and technical characteristics of gun armament. Excessively worn internal working surface of the canal of the trunk of repair and restoration is practically not subject. This determines the availability of such characteristics for cannon weaponry as the permissible number of gunfire shots, which to a certain extent limits the duration of the effective use of guns. A rather common practice in mechanical engineering is that when the strength characteristics and capabilities of the materials used are practically exhausted, designers and developers draw their views on the technological capabilities to improve the operational properties of parts and units. Not the last position in their list is the reinforcing operations of the surface layers of the material of the details by various methods of surface plastic deformation, widely known in the literary primary sources under the acronym "PPE methods". The common advantage of the best of a fairly wide variety of varieties (rolling, rolling, smoothing, blasting and vibrating processing, etc.) is that, without substituting the part for energy-intensive high-temperature heating, the strength characteristics and performance properties of the most loaded surface layers of the material of parts are improved. Accordingly, the use in manufacturing processes of the details of PPD methods helps to increase their reliability and longevity. The developed design of the reinforcement on the basis of the proposed method of vibration-centrifugal hardening treatment is used to strengthen the internal cylindrical channels of the trunk of large-caliber artillery cannons. The reinforcement is simple in structure, energy-saving, does not provide for the maintenance of highly skilled service personnel. The solid-state model of the device for the vibration-centrifugal hardening of the internal cylindrical surfaces of steel parts has been created.

Key words: hardening, surface plastic deformation, residual stresses, thickness of reinforcement, steel part, gun barrel, deformable body, solid-state modeling, animation.

\section{Розробка та моделювання пристрою для зміцнення каналів стволів гармат методом вібраційно-відцентрової обробки}

\author{
B.I. Топчій, І.С. Афтаназів, І.Г. Свідрак
}




\section{Національний університет “Львівська політехніка”, м. Львів, Україна}

У роботі пропонується принципово новий метод вібраційно-відцентрової зміцнювальної обробки внутрішніх циліндричних поверхонь довгомірних сталевих деталей, зокрема стволів артилерійських гармат, щьо належить до групи методів поверхневого пластичного деформування і вирізняється забезпеченням значного рівня енергї деформування оброблюваного матеріалу. Стволи артилерійських гармат, поряд із системою наведення прицільності стрільби, є чи не найвідповідальнішою складовою, яка не тільки забезпечує дальність та точність прицільного пострілу, а і регламентує довговічність гармати загалом. Під час кожного з пострілів гармати поверхневі прошарки металу каналу ї̈ ствола піддаються активному руйнівному впливу високих (до $1000{ }^{\circ}$ C) температур, хімічній дї порохових газів, надвисоких тисків та механічному зношуванню від переміщення по стволу снаряду. Це зумовлює руйнування структури, мічності та щільності металу поверхневих прошарків, його випалювання та зношування, шо врешті призводить до порушень геометрії робочої поверхні каналу ствола. Порушення геометрії робочої поверхні каналу ствола гармати негативно впливає на дальність, а головне - точність прицільної стрільби та інших пов'язаних із точністю тактикотехнічних характеристик гарматного озброєння. Надмірно зношена внутрішня робоча поверхня каналу ствола ремонту та відновленню практично не підляає. Це і обумовлює наявність для гарматного озброєння такої характеристики, як допустима кількість пострілів прицільної стрільби, щзо певною мірою обмежує тривалість ефективного використання гармат. Доволі розповсюдженою практикою в машинобудуванні є те, щзо коли міцнісні характеристики та можливості використовуваних матеріалів практично вичерпано, конструктори та розробники звертають свої погляди у бік технологічних можливостей поліпшення експлуатаційних властивостей деталей та вузлів. Не останню позицію у їхньому переліку посідають зміцнювальні операції поверхневих прошарків матеріалу деталей різноманітними методами поверхневого пластичного деформування, иироковідомі у літературних першоджерелах під абревіатурою “методи ППД”. Спільною перевагою краших із доволі широкої когорти їх різновидів (накатування роликом, карбування, вигладжування, дробоструменева та віброзміцнювальна обробки тощо) є те, щзо, не піддаючи деталі енергозатратному високотемпературному нагріванню, поліпшують міцністні характеристики та експлуатаційні властивості найнавантаженіших поверхневих прошарків матеріалу деталей. Відповідно використання в технологічних процесах виготовлення деталей методів ППД сприяє підвищенню їх надійності та довговічності. Розроблена конструкція зміцнювача на основі запропонованого методу вібраційно-відцентрової зміцнювальної обробки застосована для зміцнення внутрішніх циліндричних каналів стволів крупнокаліберних артилерійських гармат. Зміцнювач простий за конструктивною будовою, енергоощадний, не передбачає для обслуговування висококваліфікованого обслуговуючого персоналу. Створена твердотільна модель пристрою для вібраційновідчентрової зміцнювальної обробки внутрішніх ичиліндричних поверхонь сталевих деталей.

Ключові слова: змічнення, поверхневе пластичне деформування, залимкові напруження, товщина зміцнення, сталева деталь, канал ствола гармати, деформівне тіло, твердотільне моделювання, анімація.

\section{Вступ}

Актуальність теми. Стволи артилерійських гармат, поряд із системою наведення прицільності стрільби, є чи не найвідповідальнішою складовою, яка не тільки забезпечує дальність та точність прицільного пострілу, а і регламентує довговічність гармати загалом. Адже під час кожного із пострілів стволи піддаються певному руйнівному зношуванню. Причини, які обумовлюють зношування стволів, умовно можна розділити на три основні групи: хімічного, механічного і термічного характеру.

Під час кожного із пострілів гармати поверхневі прошарки металу каналу іiі ствола піддаються активному руйнівному впливу високих (до $1000{ }^{\circ} \mathrm{C}$ ) температур, хімічній дії порохових газів, надвисоких тисків та механічному зношуванню від переміщення по стволу снаряда. Це зумовлює руйнування структури, міцності та щільності металу поверхневих прошарків, його випалювання та зношування, що врешті призводить до порушень геометрії робочої поверхні каналу ствола. Порушення геометрії робочої поверхні каналу ствола гармати негативно впливає на дальність, а головне - точність прицільної стрільби та інших пов'язаних із точністю тактико-технічних характеристик гарматного озброєння. Надмірно зношена внутрішня робоча поверхня каналу ствола ремонту та відновленню практично не підлягає. Це і обумовлює наявність для гарматного озброєння такої характеристики як допустима кількість пострілів прицільної стрільби, яка певною мірою обмежує тривалість ефективного використання гармат.

Доволі розповсюдженою практикою в машинобудуванні є те, що коли міцнісні характеристики та мо- жливості використовуваних матеріалів практично вичерпано, конструктори та розробники звертають свої погляди у бік технологічних можливостей поліпшення експлуатаційних властивостей деталей та вузлів (Aftanaziv, 1981). Наприклад, за рахунок технологічного поліпшення характеристик найбільш навантажених поверхневих прошарків матеріалу деталей, зокрема їх шорсткості, поверхневої мікротвердості, формування спроможного протистояти експлуатаційним навантаженням напруженого стану матеріалу тощо (Kusyi \& Kuk, 2015). Яскравими прикладами такого технологічного покращення властивостей матеріалів деталей $€$ застосування при виготовленні сталевих деталей високотемпературних гартівних операцій, зокрема нормалізації, загартовування тощо, шліфування, полірування робочих поверхонь деталей та низка інших технологічних оздоблювальновикінчувальних операцій. Не останню позицію у їхньому переліку посідають і зміцнювальні операції поверхневих прошарків матеріалу деталей різноманітними методами поверхневого пластичного деформування, широковідомі в літературних першоджерелах під абревіатурою “методи ППД” (Kusyi \& Kuk, 2015).

Дослідженнями ряду вітчизняних провідних науковців минулого століття переконливо доведено, що поряд із поліпшенням міцністних характеристик матеріалу зміцнених ППД деталей на їх надійність, довговічність та спроможність протистояти експлуатаційним навантаженням визначний вплив мають сформовані в товщі зміцненого матеріалу залишкові напруження (Aftanaziv, 1981). Аналіз технологічних процесів формоутворення моноблокових гарматних стволів та лейнерів (змінних труб) багатошарових стволів, а також технологічних операцій ї подаль- 
шої механообробки засвідчує, що всі вони в кінцевому підсумку формують у товщі приповерхневих прошарків матеріалу каналу ствола напруження розтягу. Високотемпературні нагріви при пострілах, супроводжуючі їх тиски до декількох тисяч атмосфер теж спрямовані на розтяг і намагання збільшити діаметр каналу ствола, тобто експлуатаційні навантаження додатково формують у приповерхневих прошарках матеріалу експлуатаційні напруження розтягу. Просумовуючись між собою технологічні та експлуатаційні напруження розтягу сягають доволі високого градієнту, спрямованого на розрив міжмолекулярних зв'язків матеріалу на поверхні каналу стволів, на формування мікротріщин у приповерхневій товщі металу, які розростаючись при повторних пострілах, зливаючись між собою, перетворюються у втомні тріщини. Високотемпературні димові гази, що утворюються при згорянні чергового заряду, проникають у тріщини, випалюють в них метал, чим ще більше розширюють їх. Як наслідок, мікроскопічні шматки металу відшаровуються від робочої поверхні каналу ствола і згоряють у полум'ї та високотемпературних порохових газах. Як наслідок - порушується геометрія каналу ствола, погіршується точність прицільної стрільби.

Зарадити даній ситуації могло б запровадження до технологічного процесу виготовлення стволів гармат зміцнювальних операцій, що забезпечували б формування у зовнішніх прошарках матеріалу каналу ствола стискаючих напружень. Яскравим прикладом таких операцій є зміцнення поверхневим пластичним деформуванням (Kusyi \& Kuk, 2015).

Така зміцнювальна обробка забезпечує утворення у поверхневому прошарку металу оброблюваних деталей залишкових напружень стиску, формує в них поверхневий шар із підвищеною твердістю, поліпшує структуру металу в поверхневих його прошарках (Kusyi \& Kuk, 2015). Якісне поверхневе пластичне деформування (ППД) конічних та циліндричних поверхонь каналу стволів спроможне підвищити надійність та довговічність цих вартісних та відповідальних деталей завдяки підвищенню опору їх металу експлуатаційним циклічним навантаженням та зменшенню швидкості розростання мікротріщин. Адже на противагу напруженням розтягу в товщі робочих приповерхневих прошарків матеріалу, які немов би “розтягують” мікротріщину та нарощують їі довжину, напруження стиску протидіють відшаровуванню та розривам суцільності матеріалу (Aftanaziv \& Shevchuk, 2018).

Незважаючи на значну кількість науковцівдослідників, які розробляли і досліджували різноманітні методи зміцнення деталей поверхневим пластичним деформуванням, зокрема висвітлені в роботах Петросова В.В., Папшева Д.Д., Кудрявцева В.С., Олійника Н.В., Бабічева А.П. та інших, нині практично відсутній придатний для зміцнення каналів стволів гармат метод зміцнювальної обробки ППД.

Мета і завдання дослідження. Метою дослідження у даній роботі є розробка нової технології та обладнання для ефективного зміцнення поверхневим пла- стичним деформуванням внутрішніх поверхонь довгомірних деталей, зокрема каналів крупнокаліберних гарматних стволів для підвищення їх міцністних характеристик, надійності та довговічності.

У завдання дослідження входили такі етапи:

- аналіз експлуатаційних навантажень, що діють на матеріал каналу ствола гармати при стрільбі;

- аналіз технологічних можливостей та ефективності відомих різновидів методів поверхневого пластичного деформування у контексті придатності їх для зміцнення каналу стволів гармат;

- розробка та моделювання конструктивної схеми нового зміцнювального технологічного обладнання, придатного для ефективної зміцнювальної обробки каналу стволів гармат;

- аналіз технологічних можливостей новоствореного методу зміцнення внутрішніх поверхонь довгомірних деталей.

\section{Матеріал і методи досліджень}

У Національному університеті “Львівська політехніка” групою науковців під керівництвом професора Афтаназіва I.C. запропоновано принципово новий метод зміцнення поверхневим пластичним деформуванням деталей круглого поперечного перерізу, названого авторами вібраційно-відцентровою зміцнювальною обробкою (ВВ3О) (Aftanaziv, 1981). Відмінною особливістю цієї зміцнювальної обробки $\epsilon$ те, що завдяки співударянням масивних оброблюваної деталі та інструменту при контактуванні їх через незначну кількість деформівних тіл в матеріалі оброблюваної деталі в місцях ударного контакту формуються значні контактні напруження, що обумовлюють високий ступінь зміцнення та формування залишкових напружень стиску значного градієнту (Kusyi \& Kuk, 2015). Суть методу зміцнювальної обробки розкривається в описі пристрою, який його здійснює.

На рис. 1 (а, б, в) схематично відображено розміщення всередині каналу ствола гармати пристрою для його зміцнення вібраційно-відцентровою зміцнювальною обробкою (рис. 1а), на рис. 1б - перпендикулярний геометричній осі ствола переріз А - A (рис. 1а) у нижній точці розташування зміцнювача, на рис. 1в вид за напрямком, вказаномим стрілкою Б (рис. 1a), із відображенням діючих на зміцнювач сил в процесі зміцнювальної обробки.

Зміцнення поверхневим пластичним деформуванням внутрішньої поверхні каналу стволів артилерійських гармат відповідно до вібраційно-відцентрової зміцнювальної обробки здійснюють таким чином.

Зміцнювальний пристрій, до складу якого входять електропривід 1, циліндричний зміцнювач 2 із розміщеними на зовнішній його поверхні деформівними тілами 3 у вигляді сталевих загартованих кульок високої твердості та механізм 4 передачі крутного моменту та обертового руху, що з'єднує вал електроприводу із зміцнювачем 2, розташовують всередині ствола 5 гармати. 

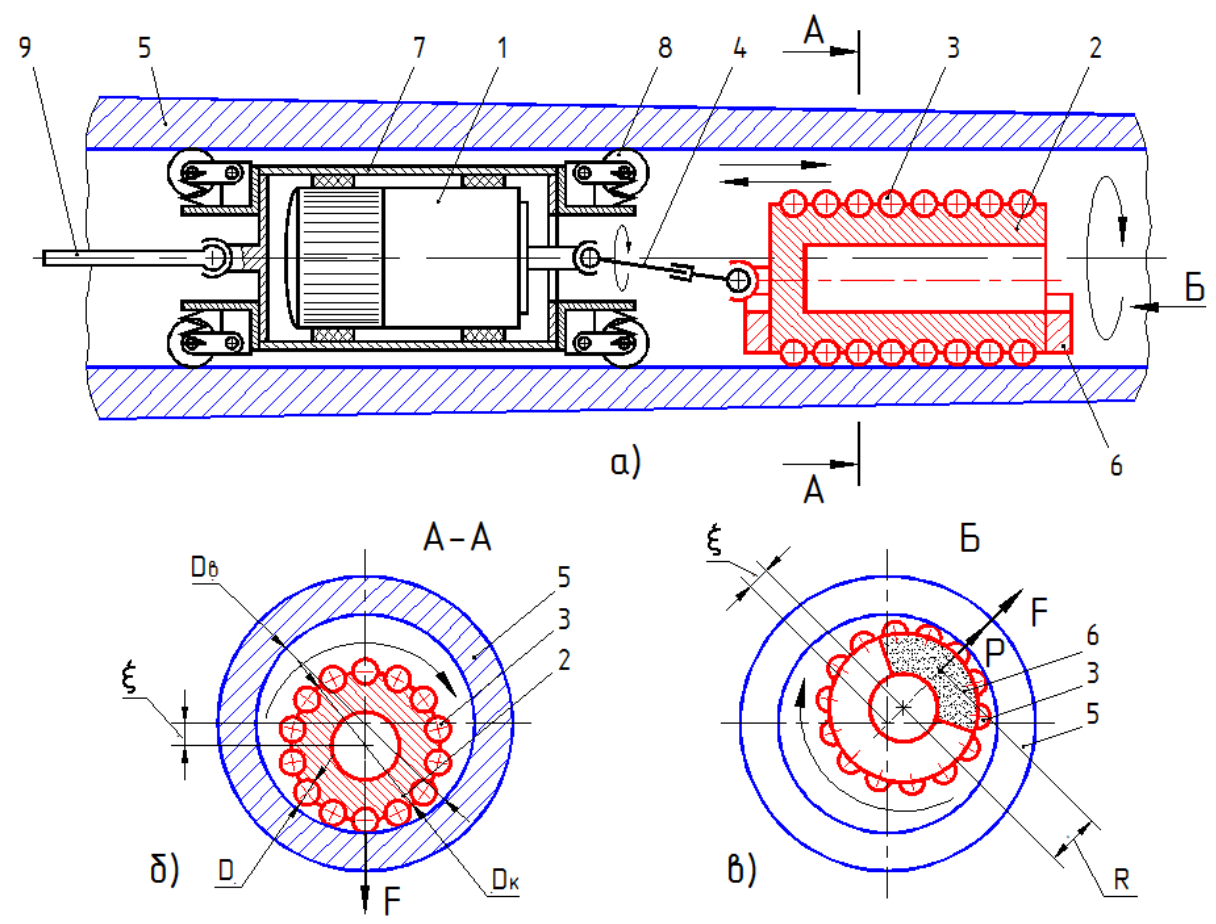

Рис. 1 (а, б, в). Пристрій для зміцнення каналу ствола гармати

Механізм 4 передачі обертового руху на зміцнювач 2 передбачає забезпечення і радіального переміщення зміцнювача відносно геометричної осі ствола гармати 5. Тому як механізм передачі крутного моменту та обертового руху доречно використовувати або карданний, або гнучкий вал. На зміцнювачі 2 зафіксовано дебаланси 6 (рис. 1в). Електропривід 1 розміщено у корпусі 7, який за допомогою роликів 8 відцентровано співвісно оброблюваній поверхні ствола гармати 5. Зміцнювальний пристрій розташовують всередині внутрішньої оброблюваної поверхні ствола гармати 5, а для його переміщень вздовж твірної зміцнюваної поверхні призначено приєднаний до корпуса 7 трос 9, що намотується на барабан лебідки (на рис.1 не відображено).

Максимальний діаметр кола $D_{3 м}$, що охоплює розміщені на зміцнювачі 2 деформівні кульки 3, приймають рівним

$$
D_{3 м}=(0,75-0,85) \cdot D_{6},
$$

де $D_{6}$ - діаметр внутрішньої зміцнюваної поверхні ствола гармати, тобто його каналу в циліндричній частині.

Ексцентриситет $\varepsilon$ зміцнювача 2 із деформівними кульками 3 дорівнює

$$
\varepsilon=\frac{D_{6}-\left(\mathrm{D}_{\mathrm{K}}+\mathrm{D}\right)}{2},
$$

де $D$ - діаметр сферичних деформівних сталевих загартованих кульок 3 ;

$D_{s}$ - діаметр внутрішньої зміцнюваної поверхні ствола гармати;

$D_{\kappa}$ - діаметр кола розташування геометричних центрів сферичних деформівних кульок 3 .

Із умови забезпечення заданої якості зміцнювальної обробки, яка регламентується товщиною зміцненого прошарку металу, нерозривно пов'язаною із діаметром відбитків на обробленій поверхні після іiі ударної взаємодії із деформівними кульками 3 та механічними властивостями зміцнюваного матеріалу, величину ексцентриситету $\varepsilon$ уточнюють по залежносTi

$$
\varepsilon=\frac{\sigma_{m} \cdot d^{2} \cdot l}{50 \cdot m \cdot D \cdot n^{2}},
$$

де $\varepsilon$ - ексцентриситет зміщення центру маси зміцнювача 2 відносно геометричної осі оброблюваної поверхні ствола гармати 5;

$n$ - частота обкочування зміцнювача 2 по внутрішній поверхні каналу ствола 5 ;

$\sigma_{m}$ - межа текучості матеріалу зміцнюваного ствола гармати 5 ;

$m$ - маса зміцнювача 2 із деформівними кульками 3 та дебалансами 6;

$d$ - діаметр відбитка на оброблюваній поверхні від ударного контакту деформівної кульки 3 із стволом 5 ;

$D$ - діаметр сферичних деформівних кульок 3 ;

$l$ - довжина твірної зовнішньої циліндричної поверхні зміцнювача 2, на якій встановлено деформівні кульки 3.

Для забезпечення робочого обкочувального руху на зміцнювачі 2 закріплено дебаланси 6, масу яких та віддаль центра маси від осі обертання зміцнювача 2 визначають із залежності

$$
m_{\text {Д }}=\frac{\varepsilon \cdot m}{2 R-\varepsilon},
$$

де $\mathrm{m}_{\text {д }}$ - масса дебаланса 6;

$\mathrm{m}$ - маса зміцнювача 2 із деформівними кульками 3 ;

$\varepsilon$ - ексцентриситет зміцнювача 2 ;

$\mathrm{R}$ - віддаль від центра маси дебаланса 6 до осі його обертання.

На рис. 1(а, б, в) напрями переміщення та обертання зміцнювача 2 вказано стрілками. 
Зміцнення поверхневим пластичним деформуванням каналу ствола гармати із використанням даного зміцнювального пристрою здійснюють таким чином. Зміцнювальний пристрій встановлюють всередину каналу ствола 5 гармати і подають напругу живлення на його електродвигун приводу 1 (рис. 1а). При подачі напруги живлення на електродвигун приводу 1 крутний момент від його валу через механізм 4 передачі обертового руху (карданний або гнучкий вал) передається зміцнювачу 2, який набуває при цьому обертового руху із частотою, рівною частоті обертання валу електроприводу 1 (рис. 1б). У процесі обертання зміцнювача 2 при обертанні прикріплених до зміцнювача дебалансів 6 на зміцнювач діє збурююча сила Р (рис. 1в), що рівна добутку маси дебалансів на віддаль від центра їх маси до осі обертання. Обертовий вектор дії сили Р проходить через вісь обертання зміцнювача та центр маси дебалансів 6. За умови дотримання величин маси дебалансів 6 та віддалі від осі обертання до центра маси, обумовлених залежністю (2), зміцнювач 2 під дією переданого йому крутного моменту та сили Р самовтягується у режим робочого планетарного обкочувального руху по внутрішній оброблюваній поверхні каналу ствола 5 з розташованими на його зовнішній циліндричній поверхні деформівними кульками 3.

При обкочувальному русі зміцнювача 2 по внутрішній оброблювальній поверхні деталі 5 на зміцнювач діє відцентрова сила $F$, обертовий вектор дії якої спрямований від центра маси зміцнювача і проходить перпендикулярно геометричним осям зміцнювача i оброблюваної поверхні (рис. 1). На рис. 16 напрям дії відцентрової сили відображено стрілкою із буквеним позначенням F. Величина цієї відцентрової сили $F$ пропорційна масі $m$ та ексцентриситету $\varepsilon$ зміцнювача 2 і квадрату кругової частоти $n$ його обкочувального руху і визначається із залежності

$$
F=m \cdot \varepsilon \cdot \omega^{2}
$$

де $\omega=2 \pi n-$ кругова частота обкочувального руху зміцнювача 2.

У будь-який проміжок часу зміцнювач 2 контактує із оброблюваною поверхнею каналу ствола 5 через деформівні кульки 3, розміщені вздовж твірної циліндричної зовнішньої поверхні зміцнювача. Контакт із черговою групою деформівних кульок 3 , розміщених вздовж твірної зміцнювача, відбувається 3 ударною взаємодією. При цьому сила удару, що припадає на кожне із деформівних тіл 3, пропорційна відцентровій силі $F$, що діє на обертовий зміцнювач, і обернено пропорційна кількості $N=l / D$ розташованих вздовж твірної зміцнювача деформівних кульок 3 , тобто

$$
F_{y}=\frac{F}{N}=\frac{m \cdot \varepsilon \cdot D \cdot \omega^{2}}{l},
$$

де $l$ - довжина твірної циліндричної поверхні зміцнювача 2,

$N$ - кількість деформівних кульок 3 , розміщених вздовж твірної зміцнювача 2.

Величину контактних напружень, що повинні забезпечуватися в місцях контакту із деформівними кульками 3 в приповерхневих прошарках матеріалу оброблюваної поверхні у результаті ударної взаємодії, призначають рівними межі текучості $\sigma_{m}$ оброблюваного матеріалу і визначають із залежності

$$
\sigma_{\text {кон }}=\frac{\mathrm{F}_{\mathrm{y}}}{\mathrm{S}}=\frac{10 \cdot m \cdot \varepsilon \cdot D \cdot n^{2}}{l \cdot d^{2}},
$$

де $S=\frac{\pi \mathrm{d}^{2}}{4} \quad$ площа належного для забезпечення якісного зміцнення оброблюваної поверхні каналу ствола 5 залишкового відбитку після ударного контакту із деформівним сферичним тілом (кулькою).

Обкочувальний рух зміцнювача 2 по внутрішній оброблюваній поверхні каналу ствола 5 здійснюють одночасно із рівномірним осьовим переміщенням зміцнювального пристрою вздовж твірної зміцнюваної поверхні за допомогою троса 9.

На рис. 2 показана твердотільна модель пристрою для зміцнення гарматних стволів, яка розташована всередині каналу ствола гармати.

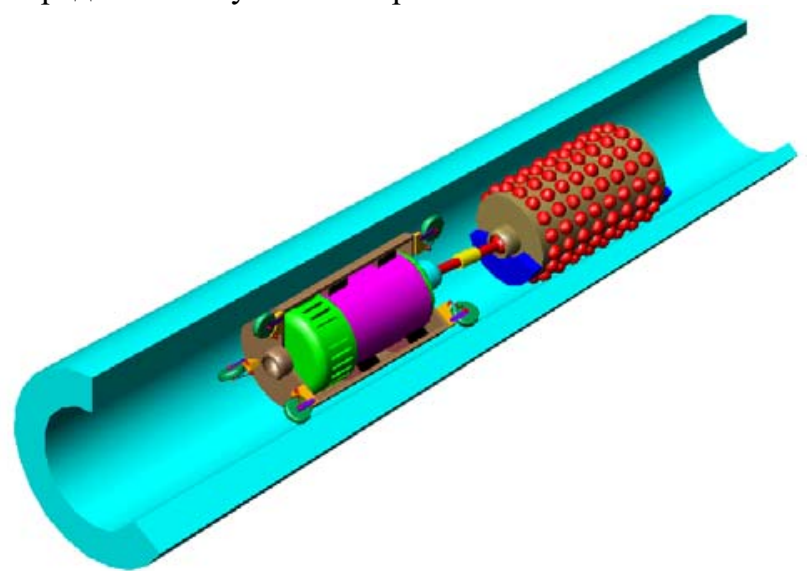

Рис. 2. Модель пристрою для зміцнення розташованого всередині каналу ствола гармати

Перевірку технологічних можливостей методу вібраційно-відцентрового зміцнення здійснювалося на моделі гарматного ствола із діаметром внутрішньої поверхні $D_{6}=125 \mathrm{Mm}$, виготовленого із легованої конструкційної сталі марки $12 \mathrm{XH} 3 \mathrm{~A}$ із межею текучості матеріалу $\sigma_{m}=750$ МПа.

\section{Результати та їх обговорення}

Отже, зміцнювальна обробка забезпечує утворення у поверхневому прошарку металу оброблюваних деталей залишкових напружень стиску, формує в них поверхневий шар із підвищеною твердістю, поліпшує структуру металу в поверхневих його прошарках. Якісне поверхневе пластичне деформування (ППД) конічних та циліндричних поверхонь каналу стволів спроможне підвищити надійність та довговічність цих вартісних та відповідальних деталей завдяки підвищенню опору їх металу експлуатаційним циклічним навантаженням та зменшенню швидкості розростання мікротріщин. Адже на противагу напруженням розтягу в товщі робочих приповерхневих прошарків матеріалу, які немов би “розтягують" мікротріщину та нарощують іiі довжину, напруження стиску протидіють відшаровуванню та розривам суцільності матеріалу. 
Проте особливості конструктивної будови таких специфічних деталей, як стволи гармат, обумовлюють певні труднощі при використанні для їх зміцнення відомих методів ППД. Специфіка у складності застосування для зміцнення каналу стволів відомих методів ППД полягає виключно у конструктивній будові стволів гармат, а саме у значній протяжності робочої поверхні каналу ствола, який підлягає зміцненню, та незначному його діаметрі. Тобто, це є великогабаритна масивна довгомірна трубчаста деталь довжиною від двох до шести метрів при діаметрі приналежної для зміцнення внутрішньої поверхні в діапазоні 125250 мм. До того ж зміцнити цю протяжну внутрішню поверхню каналу ствола необхідно не $з$ метою поліпшення чистоти поверхні, а якісно проклепати для наведення у товщі матеріалу напружень стиску значного градієнту. Ця ситуація унеможливлює використання всіх статичних методів ППД (накатування роликом, вигладжування тощо), а також таких розповсюджених методів динамічного зміцнення, як віброударна чи дробоструменева обробки через недостатню енергію деформування матеріалу деталі, обмежену незначною масою деформівних кульок чи дробу. За параметрами енергетичних можливостей тут могло б конкурувати хіба що карбування (рос. - чеканка), та воно непридатне для зміцнення таких протяжних, та ще і внутрішніх поверхонь.

Метод вібраційно-відцентрової зміцнювальної обробки належить до групи методів динамічного поверхневого зміцнення, забезпечує товщини зміцненого шару матеріалу сталевих деталей $0,15 \div 0,20$ мм. Завдяки значній енергії ударної взаємодії інструмента 3 матеріалом оброблюваної деталі в поверхневих іiі прошарках формуються залишкові напруження стиску значного градієнту. Як наслідок, це підвищує міцність та надійність зміцнених деталей.

Розроблена конструкція зміцнювача на основі запропонованого методу вібраційно-відцентрової зміцнювальної обробки застосована для зміцнення внутрішніх циліндричних каналів стволів крупнокаліберних артилерійських гармат. Зміцнювач простий за конструктивною будовою, енергоощадний, не передбачає для обслуговування висококваліфікованого обслуговуючого персоналу.

Перевірку технологічних можливостей методу вібраційно-відцентрового зміцнення здійснювалося на моделі гарматного ствола із діаметром внутрішньої поверхні $\mathrm{D}_{\text {в }}=125$ мм, виготовленого із легованої конструкційної сталі марки $12 \mathrm{XH} 3 \mathrm{~A}$ із межею текучості матеріалу $\sigma_{\mathrm{T}}=750 \mathrm{MПа}$, яка за своїми фізикомеханічними властивостями наближена певною мірою до матеріалів, що використовуються для виготовлення гарматних стволів.

Межі висоти зміцненого шару $-h=0,15 \div 0,20$ мм.

Діаметр відбитків на оброблюваній поверхні $-d=$ $2 h=2 \cdot 0,20=0,40$ мм.

Геометричні параметри зміцнювача та параметри обробки:

- діаметр деформівних тіл $D=10$ м ;
- довжина зміцнювача $l=0,5 \mathrm{~m}$;

- масса зміцнювача із деформівними тілами $m=$ Зокг;

- кількість деформівних тіл вздовж твірної зміцнювача $N=50$;

- частота обертання валу двигуна електроприводу $n=940$ об $/ x_{8}=161 / \mathrm{c}$.

Створена твердотільна модель пристрою для вібраційно-відцентрової зміцнювальної обробки внутрішніх циліндричних поверхонь сталевих деталей.

\section{Висновки}

1. Створено принципово новий метод вібраційновідцентрової зміцнювальної обробки. Завдяки значній енергії ударної взаємодії інструмента 3 матеріалом оброблюваної деталі в поверхневих іiі прошарках формуються залишкові напруження стиску значного градієнта. Як наслідок, це підвищує міцність та надійність зміцнених деталей.

2. Вперше запропонована конструкція зміцнювача для зміцнення каналів стволів крупнокаліберних артилерійських гармат.

3. Створена твердотільна модель пристрою для вібраційно-відцентрової зміцнювальної обробки внутрішніх циліндричних поверхонь сталевих деталей.

Перспективи подальших досліджень. Крім зміцнення внутрішніх поверхонь танкових та артилерійських гармат великого калібру, дані конструкції пристроїв придатні для якісної зміцнювальної обробки зовнішніх та внутрішніх поверхонь труб високого тиску, зовнішніх поверхонь танкових торсіонних валів та торсіонних валів великотоннажних самохідних артилерійських установок, бурових та обсадних труб бурильних установок тощо.

\section{References}

Aftanaziv, I.S. (1981). Optimizacija parametrov vibracionno-centrobezhnoj uprochnjajushhej obrabotki barabanov aviacionnyh koles. Vestnik L'vovskogo politehnicheskogo instituta "Tehno-logija mashinostroenija i dinamicheskaja prochnost' mashin". L'vov: Vishha shkola, Izd-vo pri L'vov. unte, 162, 10-12 (in Russian).

Kusyi, Ya.M., \& Kuk, A.M. (2015). Rozroblennia metodu vibratsiino-vidtsentrovoho zmitsnennia dlia tekhnichnoho zabezpechennia bezvidmovnosti detalei mashyn. Vostochno-Evropejskij zhurnal peredovyh tehnologij, 1/7(73), 41-51. doi: 10.15587/1729-4061.2015.36336 (in Ukrainian).

Aftanaziv, I.S., \& Shevchuk, L.I. (2018). Prystrii dlia zmitsnennia poverkhne-vym plastychnym deformuvanniam vnutrishnikh tsylindrychnykh poverkhon dovhomirnykh detalei. Patent № 116268 Ukraina, MPK V24V 39/02 (2006.01), V23R 9/04 (2006.01). Zaiavl. 23.02.2016; Opubl. 26.02.2018, Biul. №4 (in Ukrainian). 